\title{
STUDI FAKTOR - FAKTOR LINGKUNGAN FISIK RUMAH PENDERITA DBD DI WILAYAH KERJA PUSKESMAS PURWOKERTO SELATAN KABUPATEN BANYUMAS TAHUN 2014
}

\author{
Donei Ajian Veronica *), Arif Widyanto, S.Pd., M.Si ${ }^{*}$ )
}

Abstract

Dengue Hemorrhagic Fever (DHF) disease is an infection disease caused by Dengue virus transmitted primarily through bites of Aedes aegypti. Based on the Purwokerto Selatan Public Health Center repotrs the number of dengue cases incedence from January to December 2013 recorded 92 cases.

The research objective was to describe physical house environment factors of DHF patients at district Purwokerto Selatan Public Health Center like height of place, rainfall, ilumination, air temperatur, air humidity, kind of breeding place, and mosquito larva density (C.I, H.I, B.I, ABJ). The sample cases were all patients with dengue in the public health center Purwokerto Selatan 2013.

The research result shows from 77 patient was observation as subyek of cases DHF with age between 11-15 years old are 14 people (18,18\%), 66,23\% are man with total 51 people, 46, $75 \%$ are students with total 36 people. Height of places average are 74 meters from surface of the sea. Rainfall $3.940 \mathrm{~mm}$. Average of ilumination for part in the house 130 lux, part out of the house 443 lux. Average air temperature for part in the house $310 \mathrm{C}$, part out of the house $320 \mathrm{C}$. Average air humidity part in the house $66 \%$, part out of the house 62\%. Total container was found are 285 container. C.I=2,45\%, H. $I=9,09 \%$, B. $I=9,09 \%$, dan $A B J=90,0 \%$.

Kind of breeding place was found are basin for bath, place for clean water, vase, dispenser, refrigerator, pail, aquarium, pond, second objects, and container for drink bird. Mosquito larva density C.I

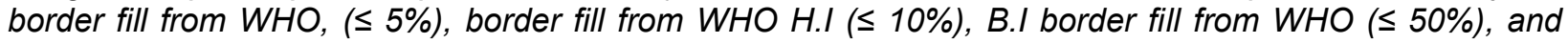
ABJ border fill from WHO ( $\geq 95 \%$ ) because of that be needed do restraint for mosquito larva. Give a suggestion to all people for do combat mosquito breeding place in other that cases

DHF can disappear or go down.

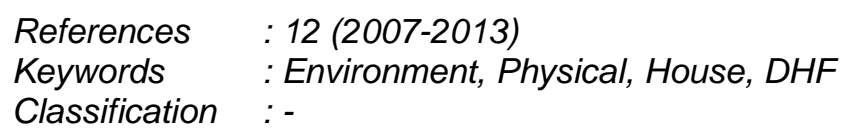

*) Alumni Mahasiswa Jurusan Kesehatan Lingkungan Purwokerto

${ }^{* *}$ ) Dosen Jurusan Kesehatan Lingkungan Purwokerto

\section{PENDAHULUAN}

\section{A. Latar Belakang}

Menurut Undang-Undang Republik Indonesia nomor 36 Tahun 2009 tentang kesehatan pasal 162 menyebutkan bahwa upaya kesehatan lingkungan ditujukan untuk mewujudkan kualitas lingkungan yang sehat, baik fisik, kimia, biologi, maupun sosial serta memungkinkan setiap orang mencapai derajat kesehatan setinggi-tingginya. Dalam rangka mewujudkan derajat kesehatan, maka pencegahan penularan penyakit menular wajib dilakukan oleh masyarakat termasuk penderita penyakit menular melalui perilaku hidup bersih dan sehat.

Lingkungan yang tidak sehat dan tidak seimbang akan memunculkan penyakitpenyakit yang berbasis lingkungan seperti : Demam Berdarah, Malaria, Diare, Cacingan, TB Paru dan penyakit berbasis lingkungan lainnya. Salah satu penyakit yang berbasis lingkungan dan memiliki angka kematian yang cukup tinggi yaitu Demam Berdarah Dengue (DBD) yang dapat bermanifestasi sebagai Dengue Shock Syndrome (DSS) merupakan penyakit menular tidak langsung. Cara penularannya melalui vektor nyamuk Aedes aegypti dan Aedes albopictus, terutama nyamuk Aedes aegypti yang habitatnya berada di dalam dan di sekitar rumah. Penyakit DBD merupakan masalah kesehatan yang harus diwaspadai, karena sering menimbulkan wabah dan kematian terutama pada anak-anak.

Jumlah kasus Demam Berdarah Dengue (DBD) di Kabupaten Banyumas pada 5 (lima) tahun terakhir mengalami peningkatan dan penurunan. Hasil pendataan dari Dinas Kesehatan Kabupaten Banyumas jumlah kasus DBD adalah sebagai berikut : 685 orang (th 2008), 382 orang (th 2009), 696 orang (th 2010), 201 orang (th 2011), dan 199 orang (th 2012). Peningkatan kasus terjadi di sekitar wilayah ibukota kabupaten (wilayah perkotaan) yang pada tahun 2009 kasusnya cukup tinggi, dari 382 kasus menjadi 696 kasus di tahun 2010.

Berdasarkan hasil laporan Dinas Kesehatan Kabupaten Banyumas Tahun 
2013, wilayah Puskesmas Purwokerto Selatan merupakan daerah dengan jumlah kasus tertinggi di wilayah Kabupaten Banyumas. Pada tahun 2013 terjadi 92 kasus $\mathrm{DBD}$, dengan rincian pada kelurahan Berkoh terdapat 5 kasus, kelurahan Tanjung 14 kasus, Purwokerto Kulon 5 kasus, Karang Klesem 17 kasus, kelurahan Teluk 20 kasus, Purwokerto Kidul 10 kasus dan yang tertinggi terdapat di kelurahan Karang Pucung dengan 21 kasus DBD.

Secara alamiah penyakit DBD dipengaruhi oleh status ekologi dengan sejumlah faktor lingkungan fisik, lingkungan biologik dan imunitas dari host. Lingkungan fisik yang terkait adalah macam tempat penampungan air (TPA) baik di dalam maupun di luar rumah, ketinggian tempat, curah hujan, hari hujan, kecepatan angin, suhu udara, tata guna tanah, pestisida dan kelembaban udara. Sedangkan lingkungan biologi yang terkait adalah banyaknya tanaman hias dan tanaman pekarangan (Ditjen. PP \& PL, 2007).

Dari ekologi vektor dapat diketahui bahwa nyamuk Aedes aegypti yang dipengaruhi oleh beberapa faktor sehingga menjadi infekted dan menularkan penyakit DBD maka peneliti tertarik untuk melakukan penelitian, dengan judul : "Studi Faktor - Faktor Lingkungan Fisik Rumah Penderita DBD di Wilayah Kerja Puskesmas Purwokerto Selatan Kabupaten Banyumas Tahun 2014".

\section{B. Masalah}

Bagaimana faktor-faktor lingkungan fisik rumah penderita DBD di wilayah kerja Puskesmas Purwokerto Selatan Kabupaten Banyumas tahun 2014 ?

\section{Tujuan}

\section{Tujuan Umum}

Mendeskripsikan

faktor-faktor lingkungan fisik rumah penderita DBD di wilayah kerja Puskesmas Purwokerto Selatan Kabupaten Banyumas tahun 2014.

2. Tujuan Khusus

a. Mendeskripsikan faktor ketinggian tempat di wilayah kerja Puskesmas Purwokerto Selatan Kabupaten Banyumas tahun 2014.

b. Mendeskripsikan faktor curah hujan di wilayah kerja Puskesmas Purwokerto Selatan Kabupaten Banyumas tahun 2014.

c. Mengukur faktor pencahayaan di rumah penderita Demam Berdarah Dengue di wilayah kerja Puskesmas Purwokerto Selatan Kabupaten Banyumas tahun 2014. d. Mengukur faktor suhu di dalam dan luar rumah penderita Demam Berdarah Dengue di wilayah kerja Puskesmas Purwokerto Selatan Kabupaten Banyumas tahun 2014.

e. Mengukur faktor kelembaban udara di dalam dan luar rumah penderita Demam Berdarah Dengue di wilayah kerja Puskesmas Purwokerto Selatan Kabupaten Banyumas tahun 2014.

f. Mendeskripsikan jenis tempat penampungan air/ tempat perindukan (TPA) di rumah penderita Demam Berdarah Dengue di wilayah kerja Puskesmas Purwokerto Selatan Kabupaten Banyumas tahun 2014.

g. Menghitung kepadatan jentik (Countainer indexl C.I) di rumah penderita Demam Berdarah Dengue di wilayah kerja Puskesmas Purwokerto Selatan Kabupaten Banyumas tahun 2014.

h. Menghitung kepadatan jentik (House index/ H.I) di rumah penderita Demam Berdarah Dengue di wilayah kerja Puskesmas Purwokerto Selatan Kabupaten Banyumas tahun 2014.

i. Menghitung kepadatan jentik (Breteau index/ B.I) di rumah penderita Demam Berdarah Dengue di wilayah kerja Puskesmas Purwokerto Selatan Kabupaten Banyumas tahun 2014.

j. Menghitung kepadatan jentik (Angka Bebas Jentik/ ABJ) di rumah penderita Demam Berdarah Dengue di wilayah kerja Puskesmas Purwokerto Selatan Kabupaten Banyumas tahun 2014.

\section{Manfaat}

1. Bagi Masyarakat

Masyarakat dapat mengetahui mengenai penyakit Demam Berdarah Dengue (DBD) terutama faktor-faktor yang berpengaruh dalam perkembangan penyakit Demam Berdarah Dengue (DBD), sehingga masyarakat dapat melakukan tindakan kewaspadaan dini dalam menghadapi penyakit Demam Berdarah Dengue (DBD).

2. Bagi Pemerintah

Digunakan sebagai bahan masukan dan pertimbangan bagi pemerintah dan instansi Kabupaten Banyumas melalui Dinas Kesehatan Kabupaten Banyumas dalam menentukan kebijakan operasional dan strategi efisien dalam pelaksanaan penanggulangan Demam Berdarah Dengue (DBD) yang terjadi pada masyarakat.

3. Bagi Almamater

Bagi Jurusan Kesehatan Lingkungan Purwokerto sebagai masukan ilmu 
pengetahuan untuk membantu memecahkan masalah kesehatan khususnya tentang Demam Berdarah Dengue (DBD) dan menambah daftar kepustakaan serta dapat menjadi acuan penelitian berikutnya.

4. Bagi peneliti

Untuk menambah pengetahuan dan pengembangan peneliti dalam hal analisis permasalahan kesehatan lingkungan di lapangan khususnya pengembangan ilmu tentang penyakit.

\section{METODE PENELITIAN}

\section{A. Kerangka Pikir}

1. Kerangka pikir

Faktor Lingkungan Fisik Rumah
Penderita DBD:
1. Ketinggian tempat
2. Curah hujan
3. Pencahayaan
4. Suhu udara
5. Kelembaban udara
6. Tempat perindukan TPA
7. Angka Bebas Jentik (ABJ)
8. Container index (C.I)
9. Breteau index (B.I)
10. House index (H.I)

Gambar 2.1 Kerangka Pikir

\section{B. Jenis Penelitian}

Jenis penelitian yang akan dilakukan menggunakan metode observasional yang bertujuan mendeskripsikan faktor-faktor lingkungan fisik pada rumah penderita DBD di wilayah kerja Puskesmas Purwokerto Selatan, Kabupaten Banyumas.

\section{Ruang Lingkup}

1. Waktu Penelitian

a. Tahap Persiapan : Oktober 2013 April 2014

1) Penentuan masalah penelitian

2) Perumusan judul

3) Pembuatan proposal KTI

4) Seminar proposal KTI

b. Tahap Pelaksanaan : Mei 2014 - Juni 2014

1) Pengumpulan data

2) Survei ke lokasi penelitian

c. Tahap Penyelesaian : Juni 2014

1) Pengolahan data

2) Analisis data

3) Penyusunan Karya Tulis IImiah

2. Lokasi

Lokasi penelitian ini adalah di wilayah kerja Puskesmas Purwokerto Selatan Kabupaten Banyumas yaitu di Kelurahan Karang Pucung, Teluk, Berkoh, Tanjung, Karang Klesem, Purwokerto Kulon, dan Purwokerto Kidul.

\section{Materi}

Ruang lingkup materi penelitian adalah semua kajian yang berhubungan dengan demam berdarah pada umumnya dan materi yang berhubungan dengan penelitian ini pada khususnya.

\section{Subyek}

Subyek penelitian ini adalah semua rumah penderita Demam Berdarah Dengue (DBD) di wilayah Puskesmas Purwokerto Selatan dari bulan Januari sampai Desember 2013 yaitu sebanyak 92 penderita. Namun pada saat dilakukan penelitian terdapat 15 penderita yang tidak dapat menjadi responden sehingga jumlah subyek penelitian ini adalah 77 responden.

\section{E. Pengumpulan Data}

1. Jenis Data

a. Data Umum

Data mengenai gambaran umum wilayah Puskesmas Purwokerto Selatan Kabupaten Banyumas yang meliputi geografis dan demografi.

b. Data khusus

Data yang berisi hasil pengamatan variabel penelitian yaitu :
1) Suhu
2) Kelembaban
3) Pencahayaan
4) Jenis TPA
5) Jumlah TPA
6) Data kasus kejadian DBD di Puskesmas Purwokerto Selatan

2. Sumber Data

a. Data Primer

Data yang diperoleh secara langsung melalui survei dan pengukuran suhu, kelembaban, dan intensitas cahaya.

b. Data Sekunder

Data yang diambil berupa data sekunder yang diperoleh dari data yang bersumber dari dinas terkait, misalnya : Dinas Kesehatan Kabupaten Banyumas, Puskesmas Purwokerto Selatan, dan Kelurahan 7 Desa yaitu Desa Karang Pucung, Teluk, Berkoh, Tanjung, Karang Klesem, Purwokerto Kulon, dan Purwokerto Kidul.

3. Cara Pengumpulan Data

a. Wawancara dilakukan dengan berdialog langsung dengan responden atau anggota keluarganya.

b. Observasi yaitu dengan cara pengamatan dan pengukuran suhu, kelembaban udara, intensitas cahaya, jenis TPA dan perhitungan jumlah kontainer/ TPA.

c. Dokumentasi. 
b. Kepadatan Penduduk

Kepadatan penduduk di wilayah puskesmas Purwokerto Selatan pada tahun 2013 adalah sebesar 5.328,44 jiwa/km2 dengan kepadatan tertinggi di kelurahan Karangpucung sebesar $6.868,92$ jiwa/ $\mathrm{Km}^{2}$ dan terendah di kelurahan Teluk sebesar 4.240,46 jiwa $/ \mathrm{Km}^{2}$.

Tabel 3.3 :Tabel Kepadatan Penduduk Kecamatan Purwokerto Selatan Tahun 2013

\begin{tabular}{|c|c|c|c|}
\hline Kelurahan & $\begin{array}{c}\text { Jumlah } \\
\text { Penduduk }\end{array}$ & Lues Wilayah & $\begin{array}{l}\text { Kepadalan } \\
\text { Penduduk } \\
\text { (Jwwa } \mathrm{Km}^{2} \text { ) }\end{array}$ \\
\hline Karanghasam & 13.829 & 3.02 & $4.579,14$ \\
\hline Teluk & 14.894 & 3.51 & $4.240,46$ \\
\hline Perkoh & 10.153 & 1.96 & $5.458,60$ \\
\hline Purwokerto Kidus & 6.068 & 1.11 & $5.468,67$ \\
\hline Purwokarto Kulon & 6.615 & 1.18 & $5.605,83$ \\
\hline Karangpuanng & 11.551 & 1.59 & $7.264,78$ \\
\hline Taniung & 10.166 & 1.48 & $6.868,92$ \\
\hline Jumiah & 73.266 & 13.75 & $5.328,44$ \\
\hline
\end{tabular}

Sumber : BPS Kabupaten Banyumas, Hasil Proyeksi Penduduk

3. Gambaran Umum Kasus Penyakit DBD Jumlah kasus kejadian Demam Berdarah Dengue di wilayah kerja Puskesmas Purwokerto Selatan dari tahun 2009 sampai tahun 2013 sebagai berikut:

Tabel 3.4 :Jumlah Kasus DBD Dari Tahun 2009-2013 Di Wilayah Kerja Puskesmas Purwokerto Selatan Tahun 2013

\begin{tabular}{rrrr}
\hline No & Tahun & Jumlah Kasus & Jumlah Kemalian \\
\hline 1 & 2009 & 47 & 0 \\
2 & 2010 & 126 & 0 \\
3 & 2011 & 67 & 0 \\
4 & 2012 & 31 & 0 \\
5 & 2013 & 92 & 0 \\
\hline
\end{tabular}

Sumber : Data Puskesmas Purwokerto Selatan

\section{B. Analisis Univariat}

1. Karakteristik Responden

Responden kasus penelitian ini adalah penderita Demam Berdarah Dengue di wilayah kerja Puskesmas Purwokerto Selatan pada bulan Januari sampai bulan Desember tahun 2013 yang berjumlah 92 orang. Dalam penelitian ini diambil seluruh subyek yaitu berjumlah 92 orang. Pada survei pengumpulan data yang telah dilakukan didapatkan hasil data orang/ rumah yang tersurvei sebanyak 77 orang, sedangkan 15 rumah tidak dapat disurvei.

a. Jumlah responden menurut umur

Persentase dari kasus kejadian

Demam Berdarah Dengue menurut umur yang disajikan pada tabel berikut:
Tabel 3.5 :Jumlah Responden Menurut Umur di Wilayah Kerja Puskesmas Purwokerto Selatan Tahun 2013

\begin{tabular}{|c|c|c|c|}
\hline \multirow{2}{*}{ No } & \multirow{2}{*}{$\begin{array}{c}\text { Umur Responden } \\
\text { (Tahun) }\end{array}$} & \multicolumn{2}{|c|}{ KasuS } \\
\hline & & Jumlah & $\%$ \\
\hline 1 & $0-5$ & 7 & $9,09 \%$ \\
\hline 2 & 6-10 & 7 & $9,09 \%$ \\
\hline 3 & $11-15$ & 14 & $1 \mathrm{~B}, 1 \mathrm{~g} \%$ \\
\hline 4 & $16-20$ & 11 & $14,28 \%$ \\
\hline 5 & $21-25$ & 9 & $11,68 \%$ \\
\hline 6 & $26-30$ & 6 & $7,79 \%$ \\
\hline 7 & $31-35$ & 8 & $10,38 \%$ \\
\hline 8 & $36-40$ & 7 & $9,09 \%$ \\
\hline 9 & $41-45$ & 4 & $5,19 \%$ \\
\hline 10 & $46-50$ & 2 & $2,59 \%$ \\
\hline 11 & $51-55$ & 0 & $0 \%$ \\
\hline 12 & $56-60$ & 2 & $259 \%$ \\
\hline & Jumlah & 77 & $100 \%$ \\
\hline
\end{tabular}

karakteristik responden menurut umur diketahui bahwa subyek kasus paling banyak berusia 11-15 tahun dengan persentase $18,18 \%$.

b. Jumlah responden menurut jenis kelamin

Persentase dari kasus kejadian Demam Berdarah Dengue menurut jenis kelamin yang disajikan pada tabel berikut:

Tebel 3.6 :Jumlah Responden Menurut Jenis Kelamin di Wilayah Kerja Puskesmas Purwokerto Selatan Tahun 2013

\begin{tabular}{|c|c|c|c|}
\hline \multirow{2}{*}{ No } & \multirow{2}{*}{ Jenis Kelamin } & \multicolumn{2}{|c|}{ KBsuS } \\
\hline & & Jumlah & $\%$ \\
\hline 1 & Laki-laki & 51 & $66,23 \%$ \\
\hline 2 & Perempuan & 41 & $53,24 \%$ \\
\hline & Jumlah & 77 & $100 \%$ \\
\hline
\end{tabular}

karakteristik responden menurut jenis kelamin diketahui bahwa subyek kasus paling banyak berjenis kelamin lakilaki sebanyak 51 orang dengan persentase $66,23 \%$.

c. Jumlah responden menurut tingkat pendidikan

Persentase dari kasus kejadian Demam Berdarah Dengue menurut tingkat pendidikan yang disajikan pada tabel berikut:

Tabel 3.7 :Jumlah Responden Menurut Tingkat Pendidikan di Wilayah Kerja Puskesmas Purwokerto Selatan Tahun 2013

\begin{tabular}{|c|c|c|c|}
\hline \multirow{2}{*}{ No } & \multirow{2}{*}{ Tingkat Pendicikan } & \multicolumn{2}{|c|}{ Kasus } \\
\hline & & Jumiah & $\%$ \\
\hline 1 & Trdak belum tama! SO & 22 & $28,57 \%$ \\
\hline 2 & Tamat SMPI Sedarajat & 14 & $18,18 \%$ \\
\hline 3 & Tamat SMA Sedarajat & 28 & $36,38 \%$ \\
\hline 4 & Akademikf Kulliah & 13 & $16,89 \%$ \\
\hline & Jumlan & 77 & $100 \%$ \\
\hline
\end{tabular}


Berdasarkan tabel diatas, karakteristik responden menurut tingkat pendidikan diketahui bahwa subyek kasus paling banyak memiliki tingkat pendidikan tamat SMA/ sederajat sebanyak 28 orang dengan persentase $36,36 \%$.

d. Jumlah responden menurut jenis pekerjaan

Persentase dari kasus kejadian Demam Berdarah Dengue menurut jenis pekerjaan yang disajikan pada tabel berikut:

Tabel 3.8 Jumlah Responden Menurut Jenis Pekerjaan di Wilayah Kerja Puskesmas Purwokerto Selatan Tahun 2013

\begin{tabular}{|c|c|c|c|}
\hline \multirow{2}{*}{ No } & \multirow{2}{*}{ Janis Pakerjaan } & \multicolumn{2}{|c|}{ Kagus } \\
\hline & & Jumiah & $\%$ \\
\hline 1 & PNS & 5 & $6,49 \%$ \\
\hline 2 & Swasta & 16 & $20,77 \%$ \\
\hline 3 & Palajar/ Manasiswa & 36 & $46,75 \%$ \\
\hline 4 & Ibu Rumah Tarpga (IRT) & 12 & $15.59 \%$ \\
\hline 5 & Belum bekeria & 8 & $10,39 \%$ \\
\hline Jumlah & & 77 & $100 \%$ \\
\hline & $\begin{array}{l}\text { Berdasarkan } \\
\text { karakteristik respond } \\
\text { pekerjaan diketahui } \\
\text { kasus paling banya } \\
\text { pekerjaan sebagai pe } \\
\text { sebanyak } 36 \text { orang de } \\
46,75 \% \text {. }\end{array}$ & $\begin{array}{l}\text { tabel } \\
\text { an menur } \\
\text { bahwa } \\
\text { memilil } \\
\text { lajar/ mal } \\
\text { ngan per }\end{array}$ & $\begin{array}{l}\text { diatas, } \\
\text { it jenis } \\
\text { subyek } \\
\text { i jenis } \\
\text { asiswa } \\
\text { entase }\end{array}$ \\
\hline
\end{tabular}

2. Kondisi Lingkungan Fisik

a. Ketinggian tempat

Persentase dari kasus kejadian Demam Berdarah Dengue menurut ketinggian tempat yang disajikan pada tabel berikut:

Tabel 3.9 Lingkungan Fisik Menurut Ketinggian Tempat di Wilayah Kerja Puskesmas Purwokerto Selatan Tahun 2013

\begin{tabular}{|c|c|c|c|c|}
\hline \multirow[b]{2}{*}{ No } & \multirow[b]{2}{*}{ Kelurahan } & \multirow{2}{*}{$\begin{array}{l}\text { Ketinggian } \\
\text { Kelurahan } \\
\text { dari } \\
\text { Permukaan } \\
\text { Laut (m) }\end{array}$} & \multicolumn{2}{|c|}{ Kasus } \\
\hline & & & Jumlah & $\%$ \\
\hline 1. & $\begin{array}{l}\text { Karang } \\
\text { klesem }\end{array}$ & 74 & 14 & 18,18 \\
\hline 2. & Teluk & 74 & 17 & 22,07 \\
\hline 3. & Berkoh & 74 & 6 & 7,79 \\
\hline 4. & $\begin{array}{l}\text { Purwokerto } \\
\text { Kidul }\end{array}$ & 74 & 7 & 9,09 \\
\hline 5. & $\begin{array}{l}\text { Purwokerto } \\
\text { Kulon }\end{array}$ & 75 & 6 & 7,79 \\
\hline 6. & $\begin{array}{l}\text { Karang } \\
\text { Pucung }\end{array}$ & 74 & 15 & 19,48 \\
\hline 7. & Tanjung & 74 & 12 & 15,58 \\
\hline \multicolumn{3}{|c|}{ Jumlah } & 77 & 100 \\
\hline
\end{tabular}

Sumber : BPS Kabupaten banyumas

Berdasarkan tabel diatas, kondisi lingkungan fisik menurut ketinggian tempat diketahui bahwa subyek tempat dengan kasus tertinggi adalah di kelurahan Teluk sebanyak 17 orang dengan persentase $22,07 \%$.

b. Curah hujan

Persentase dari kasus kejadian Demam Berdarah Dengue menurut curah hujan yang disajikan pada tabel berikut:

Tabel 3.10 Lingkungan Fisik Menurut Curah Hujan di Wilayah Kerja Puskesmas Purwokerto Selatan Tahun 2013

\begin{tabular}{|c|c|c|c|c|}
\hline \multirow{2}{*}{ No } & \multirow{2}{*}{ Kelurahan } & \multirow{2}{*}{ Curah Hujan (mm) } & \multicolumn{2}{|c|}{ Kasus } \\
\hline & & & sumiah & \% \\
\hline 1 & Karangkesem & 3.940 & 14 & $18,18 \%$ \\
\hline 2 & Teluk & 3.940 & 17 & $22,07 \%$ \\
\hline 3 & Berkoh & 3.940 & 6 & $7,79 \%$ \\
\hline 4 & Purwokerto Kidul & 3.940 & 7 & $9,09 \%$ \\
\hline 5 & Purwokerto Kuton & 3.840 & 6 & $7,79 \%$ \\
\hline 6 & Karangpucung & 3.940 & 15 & $19,48 \%$ \\
\hline \multirow[t]{2}{*}{7} & Tanjung & 3.940 & 12 & $15,58 \%$ \\
\hline & & & 77 & $100 \%$ \\
\hline
\end{tabular}

Sumber : BPS Kabupaten Banyumas

Berdasarkan tabel diatas, kondisi lingkungan fisik menurut curah hujan diketahui bahwa subyek tempat dengan kasus tertinggi adalah di kelurahan Teluk sebanyak 17 orang dengan persentase $22,07 \%$.

c. Pencahayaan

Persentase dari kasus kejadian Demam Berdarah Dengue menurut pencahayaan yang disajikan pada tabel berikut:

Tabel 3.11 Lingkungan Fisik Menurut Pencahayaan di Wilayah Kerja Puskesmas Purwokerto Selatan Tahun 2014

\begin{tabular}{|c|c|c|c|}
\hline \multirow[t]{2}{*}{ No } & \multirow[t]{2}{*}{ Kelurahan } & \multicolumn{2}{|c|}{$\begin{array}{c}\text { Pencahayaan Rala-rala } \\
\text { (Lum) }\end{array}$} \\
\hline & & Dalem numeh & Liuar numah \\
\hline 1 & Karangdesem & 117 & 456 \\
\hline 2 & Teluk & 160 & 643 \\
\hline 3 & Berkoh & 126 & 374 \\
\hline 4 & Puwckerto Kidul & 96 & 449 \\
\hline 5 & Puwokerto Kulon & 112 & 326 \\
\hline 6 & Karangpusung & 212 & 411 \\
\hline 7 & Taniung & 87 & 445 \\
\hline & Jumiah rata-raia & 130 LLX & 443 Lux \\
\hline
\end{tabular}

Sumber : BPS Kabupaten Banyumas

Berdasarkan tabel diatas, kondisi lingkungan fisik menurut pencahayaan diketahui bahwa rata-rata pencahayaan di wilayah kerja Puskesmas Purwokerto Selatan untuk bagian dalam rumah adalah 130 lux, sedangkan untuk bagian luar rumah adalah 443 lux. Subyek tempat dengan rata-rata pencahayaan tertinggi adalah di kelurahan Karangpucung dengan rata-rata pencahayaan bagian dalam rumah adalah 212 lux dan pencahayaan bagian luar rumah terdapat di kelurahan Teluk dengan pencahayaan rata-rata 643 lux. 


\section{d. Suhu udara}

Persentase dari kasus kejadian Demam Berdarah Dengue menurut suhu udara yang disajikan pada tabel berikut:

Tabel 3.12 :Lingkungan Fisik Menurut Suhu Udara di Wilayah Kerja Puskesmas Purwokerto Selatan Tahun 2014

\begin{tabular}{|c|c|c|c|}
\hline \multirow{2}{*}{ No } & \multirow{2}{*}{ Kelurahan } & \multicolumn{2}{|c|}{ Sunu Udara $\left({ }^{\circ} \mathrm{C}\right)$} \\
\hline & & Dalam numeh & Luar rumah \\
\hline 1 & Karangiesem & 32 & 32 \\
\hline 2 & Teluk & 27 & 32 \\
\hline 3 & Berkoh & 32 & 32 \\
\hline 4 & Puwokerto Kidul & 30 & 32 \\
\hline 5 & Purwokerto Kulon & 32 & 32 \\
\hline 6 & Karangpucung & 34 & 34 \\
\hline 7 & Taniung & 30 & 30 \\
\hline & Jumlah raia-rata & $31^{2} \mathrm{C}$ & $32^{2} \mathrm{C}$ \\
\hline
\end{tabular}

Berdasarkan tabel diatas, kondisi lingkungan fisik menurut suhu udara diketahui bahwa rata-rata suhu udara di wilayah kerja Puskesmas Purwokerto Selatan untuk bagian dalam rumah adalah $31^{\circ} \mathrm{C}$ sedangkan untuk bagian luar rumah adalah $32^{\circ} \mathrm{C}$. Subyek tempat dengan rata-rata pencahayaan tertinggi adalah di kelurahan Karangpucung dengan ratarata suhu udara bagian dalam rumah dan bagian luar rumah adalah $34^{\circ} \mathrm{C}$.

e. Kelembaban udara

Persentase dari kasus kejadian Demam Berdarah Dengue menurut kelembaban udara yang disajikan pada tabel berikut:

Tabel 3.13 Lingkungan Fisik Menurut Kelembaban Udara di Wilayah Kerja Puskesmas Purwokerto Selatan Tahun 2014

\begin{tabular}{|c|c|c|c|}
\hline \multirow[b]{2}{*}{ No } & \multirow{2}{*}{ Kelurahan } & \multicolumn{2}{|c|}{ Kelambaban Udara $(x)$} \\
\hline & & Dalam rumah & Luar rumah \\
\hline 1 & Karanghesem & 60 & 62 \\
\hline 2 & Teluk & 62 & 70 \\
\hline 3 & Berkoh & 70 & 70 \\
\hline 4 & Purwokerto Kdul & 70 & 70 \\
\hline 5 & Puwsckerto Kulon & 70 & 72 \\
\hline 6 & Karangpucung & 60 & 60 \\
\hline \multirow[t]{2}{*}{7} & Tanjung & 70 & 70 \\
\hline & Jumigh rata-rala & $68 \%$ & $68 \%$ \\
\hline
\end{tabular}

Berdasarkan tabel diatas, kondisi lingkungan fisik menurut kelembaban udara diketahui bahwa rata-rata kelembaban udara di wilayah kerja Puskesmas Purwokerto Selatan untuk bagian dalam rumah adalah $66 \%$ sedangkan untuk bagian luar rumah adalah $62 \%$. Subyek tempat dengan rata-rata kelembaban tertinggi adalah di kelurahan Purwokerto Kidul, Purwokerto Kulon, dan Tanjung dengan rata-rata kelembaban udara bagian dalam rumah $70 \%$ dan bagian luar rumah di kelurahan Purwokerto Kulon adalah $72 \%$.

f. Jenis tempat penampungan air/ tempat perindukan (TPA)

Persentase dari kasus kejadian Demam Berdarah Dengue menurut jenis tempat penampungan air/ tempat perindukan (TPA) yang disajikan pada tabel berikut:

Tabel 3.14 Lingkungan Fisik Menurut Jenis TPA Di Wilayah Kerja Puskesmas Purwokerto Selatan Tahun 2014

\begin{tabular}{|c|c|c|c|c|c|c|}
\hline \multirow[b]{2}{*}{ No } & \multirow[b]{2}{*}{ Kelurahan } & \multicolumn{5}{|c|}{ Jenis TPA } \\
\hline & & $\begin{array}{l}\text { Bak } \\
\text { Mandi }\end{array}$ & $\begin{array}{c}\text { Tempa } \\
\text { yan }\end{array}$ & $\begin{array}{l}\text { Pot } \\
\text { Vas }\end{array}$ & $\begin{array}{c}\text { Dispen } \\
\text { ser }\end{array}$ & Kulkas \\
\hline (1) & (2) & (3) & (4) & (5) & $\langle 6\rangle$ & (7) \\
\hline$i$ & Karangklesem & 12 & 6 & 10 & 14 & 9 \\
\hline 2 & Teluk & 12 & 10 & 12 & 10 & 16 \\
\hline 3 & Berkoh & 5 & 5 & 4 & 2 & 5 \\
\hline 4 & Purwokarto Kidul & 5 & $s$ & 5 & 1 & 6 \\
\hline 5 & Purwokerto Kuson & 5 & 5 & 4 & 2 & 5 \\
\hline 6 & Karangpucung & 8 & 3 & 10 & 10 & 11 \\
\hline \multirow[t]{3}{*}{7} & Tanjung & 7 & 9 & 7 & 7 & 10 \\
\hline & Jumtan & 54 & 4.3 & 52 & 46 & 62 \\
\hline & & \multicolumn{5}{|c|}{ Jenis TPA } \\
\hline No & Kelurahan & Ember & $\begin{array}{c}\text { Akuan } \\
\text { um }\end{array}$ & Kolam & $\begin{array}{l}\text { Barang } \\
\text { bekas }\end{array}$ & $\begin{array}{l}\text { Tempat } \\
\text { minimm } \\
\text { burung }\end{array}$ \\
\hline (1) & $(2)$ & (8) & (9) & (10) & (11) & (12) \\
\hline 8 & Karangklesem & 2 & - & 1 & - & - \\
\hline 9 & Teluk & 3 & 1 & - & 1 & - \\
\hline 10 & Berkoh & 2 & - & - & $=$ & - \\
\hline 11 & Purwokerto Kidul & 2 & - & - & - & 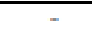 \\
\hline 12 & Purwokerto Kulon & 1 & - & - & - & - \\
\hline 13 & Karangpucung & 7 & - & - & - & 2 \\
\hline 14 & Tanjung & 4 & - & 1 & 1 & - \\
\hline & Jumlan & 20 & 2 & 2 & 2 & 2 \\
\hline
\end{tabular}

Berdasarkan tabel diatas, kondisi lingkungan fisik menurut jenis tempat penampungan air/ tempat perindukan (TPA) diketahui bahwa jumlah container yang telah diperiksa di wilayah kerja Puskesmas Purwokerto Selatan adalah 285 container.

g. Kepadatan jentik
1) Countainer index/ (C.I)
Dari hasil data yang telah dikumpulkan melalui kegiatan survei yang dilakukan di wilayah kerja Puskesmas Purwokerto Selatan yang mencakup 7 kelurahan yaitu kelurahan Karangklesem, Teluk, Berkoh, Purwokerto Kidul, Purwokerto Kulon, Karangpucung, dan kelurahan Tanjung dengan subyek penelitian sebanyak 77 rumah didapatkan hasil untuk kepadatan container sebagai berikut:
CI
$=\frac{\text { Jumlah Kontainer dengan Jentik }}{\text { Jumlah Kontainer yang Diperiksa }}$ $\times 100 \%$
$C I=\frac{7}{285} \times 100 \%$
$C I=2,45 \%$ 
2) House Index/ (HI)

Dari hasil data yang telah dikumpulkan melalui kegiatan survei yang dilakukan di wilayah kerja Puskesmas Purwokerto Selatan yang mencakup 7 kelurahan yaitu kelurahan Karangklesem, Teluk, Berkoh, Purwokerto Kidul, Purwokerto Kulon, Karangpucung, dan kelurahan Tanjung dengan subyek penelitian sebanyak 77 rumah didapatkan hasil untuk kepadatan rumah sebagai berikut:

$$
\begin{aligned}
& H I=\frac{\text { Jumlah Rumah Dengan Jentik }}{\text { Jumlah Rumah yang Diperiksa }} \\
& \times 100 \% \\
& H I=\frac{7}{77} \times 100 \% \\
& H I=9,09 \%
\end{aligned}
$$

Dari hasil data yang telah dikumpulkan melalui kegiatan survei yang dilakukan di wilayah kerja Puskesmas Purwokerto Selatan yang mencakup 7 kelurahan yaitu kelurahan Karangklesem, Teluk, Berkoh, Purwokerto Kidul, Purwokerto Kulon, Karangpucung, dan kelurahan Tanjung dengan subyek penelitian sebanyak 77 rumah $B I$ didapatkan hasil sebagai berikut:

$=\frac{\text { Jumlah Container Dengan Jentik }}{\text { Jumlah Container yang Diperiksa }}$ $\times 100 \%$

$B I=\frac{7}{77} \times 100 \%$

$B I=9,09 \%$

4) Angka Bebas Jentik/ ABJ

Dari hasil data yang telah dikumpulkan melalui kegiatan survei yang dilakukan di wilayah kerja Puskesmas Purwokerto Selatan yang mencakup 7 kelurahan yaitu kelurahan Karangklesem, Teluk, Berkoh, Purwokerto Kidul, Purwokerto Kulon, Karangpucung, dan kelurahan Tanjung dengan subyek penelitian sebanyak 77 rumah didapatkan hasil untuk angka bebas jentik sebagai berikut:

$B I=\frac{\text { Jumlah Rumah/Bangunan bebas Jentik }}{\text { Jumlah Rumah/Bangunan yang Diperiksa }}$ $\times 100 \%$

$B I=\frac{7}{77} \times 100 \%$

$B I=9,09 \%$

\section{PEMBAHASAN}

\section{A. Gambaran Umum}

1. Keadaan Geografi

Wilayah Puskesmas Purwokerto Selatan memiliki keadaan iklim tropis basah. Tekanan udara rata-rata antara $1.001 \mathrm{mbs}$, dengan suhu udara berkisar antara $21,4^{\circ} \mathrm{C}-30,9^{\circ} \mathrm{C}$. Wilayah kerja Puskesmas Purwokerto Selatan memiliki tinggi lbukota kecamatan dari permukaan laut yaitu pada $74 \mathrm{~m}$ dari permukaan laut. Pada musim hujan akan menambah genangan air sebagai tempat perindukan nyamuk dan menambah kelembaban udara. Temperatur dan kelembaban udara selama musim hujan akan sangan kondusif untuk kelangsungan hidup nyamuk, karena tingkat kelembaban optimum nyamuk adalah $60 \%$ sampai dengan $80 \%$ dan suhu optimum pertumbuhan nyamuk adalah $25^{\circ} \mathrm{C}-$ $27^{\circ} \mathrm{C}$. Sehingga menyebabkan terjadi berbagai macam penyakit menular seperti penyakit Demam Berdarah Dengue.

2. Keadaan Demografi Jumlah penduduk di wilayah kerja Puskesmas Purwokerto Selatan sebanyak 73.266 orang terdiri dari 36.437 orang penduduk laki-laki dan 36.829 orang penduduk perempuan dengan jumlah kepadatan penduduk yaitu 5.328,44 jiwa/ $\mathrm{km}^{2}$. Kepadatan penduduk di wilayah puskesmas Purwokerto Selatan pada tahun 2013 adalah sebesar 5.328,44 jiwa $/ \mathrm{km}^{2}$ dengan kepadatan tertinggi di kelurahan Karangpucung sebesar $6.868,92$ jiwa/ $\mathrm{Km}^{2}$ dan terendah di kelurahan Teluk sebesar 4.240,46 jiwa / $\mathrm{Km}^{2}$. Kepadatan penduduk memudahkan dalam penularan penyakit Demam Berdarah Dengue karena jarak antar rumah yang terlalu dekat akan mempermudah terjadinya penularan penyakit. Jika dalam suatu rumah terdapat nyamuk penular penyakit Demam Berdarah Dengue, maka kemungkinan akan menularkan penyakit dengan menggigit orang yang masih dalam keadaan belum terinfeksi yang tinggal disekitar rumah tersebut.

3. Gambaran Umum Kasus Penyakit DBD Jumlah kasus kejadian Demam Berdarah Dengue di wilayah kerja Puskesmas Purwokerto Selatan dari tahun 2009 sampai tahun 2013 mengalami peningkatan dan penurunan. Hasil pendataan dari Puskesmas Purwokerto Selatan jumlah kasus DBD adalah sebagai berikut : 47 orang (th 2009), 126 orang (th 2010), 67 orang (th 2011), 31 orang (th 2012), dan 92 orang 
(th 2013). Peningkatan kasus terjadi pada tahun 2010 kasusnya cukup tinggi, dari 47 kasus menjadi 126 kasus di tahun 2010. Pada tahun 2012 juga mengalami peningkatan dari 31 kasus pada tahun 2012 menjadi 92 kasus di tahun 2013.

Berdasarkan hasil laporan Dinas Kesehatan Kabupaten Banyumas Tahun 2013, wilayah Puskesmas Purwokerto Selatan merupakan daerah dengan jumlah kasus tertinggi di wilayah Kabupaten Banyumas. Pada tahun 2013 terjadi 92 kasus DBD, dengan rincian pada kelurahan Berkoh terdapat 5 kasus, kelurahan Tanjung 14 kasus, Purwokerto Kulon 5 kasus, Karang Klesem 17 kasus, kelurahan Teluk 20 kasus, Purwokerto Kidul 10 kasus dan yang tertinggi terdapat di kelurahan Karang Pucung dengan 21 kasus DBD.

\section{B. Analisis Univariat}

1. Karakteristik Responden

Responden kasus penelitian ini adalah penderita Demam Berdarah Dengue di wilayah kerja Puskesmas Purwokerto Selatan pada bulan Januari sampai bulan Desember tahun 2013 yang berjumlah 92 orang. Dalam penelitian ini diambil seluruh subyek yaitu berjumlah 92 orang. Pada survei pengumpulan data yang telah dilakukan didapatkan hasil data orang/ rumah yang tersurvei sebanyak 77 orang, sedangkan 15 rumah tidak dapat disurvei.

Terdapat beberapa rumah yang tidak tersurvei dan belum bisa menjadi responden disebabkan karena terdapat beberapa alasan antara lain karena tidak ditemukannya rumah responden oleh peneliti, kesalahan alamat pada data awal, responden tidak berada di rumah saat dilakukan kegiatan survei, responden belum bersedia menjadi responden untuk dilakukan kegiatan survei pengumpulan data.

a. Jumlah responden menurut umur

Berdasarkan tabel 3.5 bahwa jumlah penderita kasus Demam Berdarah Dengue dengan umur 0-5 tahun sebanyak 7 kasus, 6-10 tahun 7 kasus, 11-15 tahun 14 kasus, 16-20 tahun 11 kasus, 21-25 tahun 9 kasus, 26-30 tahun 6 kasus, 31-35 tahun 8 kasus, 36-40 tahun 7 kasus, 41-45 tahun 4 kasus, 46-50 tahun 2 kasus, dan 56-60 tahun sebanyak 2 kasus Kecenderungan meningkatnya penderita pada usia remaja antara 11 . 15 tahun dengan persentase 18,18\%, karena pada usia yang produktif menyebabkan aktivitas yang tinggi sehingga memudahkan terkena penyakit menular seperti penyakit DBD.

b. Jumlah responden menurut jenis kelamin

Berdasarkan tabel 3.6 bahwa jumlah penderita kasus Demam Berdarah Dengue dengan jenis kelamin laki-laki lebih tinggi yaitu sebanyak 51 penderita dengan persentase $66,23 \%$, dan penderita perempuan sebanyak 41 penderita dengan persentase $53,24 \%$. Penderita lebih tinggi dengan subyek laki-laki karena disebabkan mobilitas penderita yang banyak melakukan aktivitas di pagi sampai sore hari. Aktifitas seseorang yang dilakukan sehari-hari dan berpindah-pindah tanpa peduli tempat yang didatangi aman/ tidak berpengaruh terhadap timbulnya risiko terserang penyakit menular seperti penyakit DBD.

c. Jumlah responden menurut tingkat pendidikan

Berdasarkan tabel 3.7 bahwa jumlah penderita kasus Demam Berdarah Dengue dengan tingkat pendidikan tidak/ belum tamat SD sebanyak 22 kasus, tamat SMP/ sederajat 14 kasus, tamat SMA/ sederajat 28 kasus, dan menempuh pendidikan akademik/ kuliah sebanyak 13 kasus. Diketahui bahwa subyek kasus paling banyak memiliki tingkat pendidikan tamat SMA/ sederajat sebanyak 28 orang dengan persentase $36,36 \%$. Tingkatan belajar dan proses pembelajaran secara aktif mengembangkan potensial dirinya untuk memiliki kekuatan spiritual, keagamaan, pengendalian diri, kepribadian, kecerdasan akhlak mulia, serta ketrampilan yang diperlukan dirinya dan masyarakat. Pendidikan yang baik juga akan mempengaruhi cara berfikir dalam penerimaan penyuluhan dan cara pemberantasan yang dilakukan.

d. Jumlah responden menurut jenis pekerjaan

Berdasarkan tabel 3.8 bahwa jumlah penderita kasus Demam Berdarah Dengue dengan jenis pekerjaan sebagai PNS dengan jumlah kasus sebanyak 5 kasus, pekerjaan swasta 16 kasus, pelajar/ mahasiswa 36 kasus, ibu rumah tangga (IRT) 12 kasus dan belum bekerja sebanyak 8 kasus. Diketahui bahwa subyek kasus paling banyak memiliki jenis pekerjaan sebagai pelajar/ mahasiswa sebanyak 36 orang dengan persentase $46,75 \%$. 
Dalam arti luas pekerjaan adalah aktifitas utama yang dilakukan oleh manusia. Dalam arti sempit istilah pekerjaan digunakan untuk suatu tugas atau kerja yang menghasilkan uang bagi seseorang dapat juga disebut dengan profesi, pekerjaan sebagai penunjang untuk manusia melakukan aktifitas sesuai dengan tempat pekerjaan itu dilakukan tanpa mengetahui tempat kerja tersebut memiliki risiko sebagai tempat penularan penyakit seperti DBD dan akan mempengaruhi kunjungan untuk berobat ke puskesmas/ rumah sakit.

2. Kondisi Lingkungan Fisik

a. Ketinggian tempat

Berdasarkan tabel 4.9 bahwa jumlah penderita kasus Demam Berdarah Dengue dengan kondisi lingkungan fisik rumah menurut ketinggian tempat pada kelurahan Karangklesem dengan ketinggian 74 m dari permukaan laut sebanyak 14 kasus, kelurahan Teluk dengan ketinggian 74 mdpl sebanyak 17 kasus, kelurahan Berkoh dengan ketinggian 74 mdpl sebanyak 6 kasus, kelurahan Purwokerto Kidul dengan ketinggian sebanyak 7 kasus, kelurahan Purwokerto Kulon dengan ketinggian 75 mdpl sebanyak 6 kasus, kelurahan Karangpucung dengan ketinggian 74 mdpl sebanyak 15 kasus, dan kelurahan Tanjung dengan ketinggian 74 mdpl sebanyak 12 kasus. kondisi lingkungan fisik menurut ketinggian tempat diketahui bahwa subyek tempat dengan kasus tertinggi adalah di kelurahan Teluk sebanyak 17 orang dengan persentase 22,07\%.

Ketinggian tempat berpengaruh terhadap perkembangan nyamuk. Wilayah dengan ketinggian dibawah 1000 meter dari permukaan laut ditemukan nyamuk Aedes karena suhu tersebut memungkinkan bagi kehidupan nyamuk. Bila perbedaan cukup tinggi, maka perbedaan suhu udara juga cukup banyak dan akan mempengaruhi faktor-faktor yang lain seperti penyebaran nyamuk, siklus pertumbuhan parasit di dalam tubuh nyamuk dan musim penularan.

b. Curah hujan

Berdasarkan tabel 3.10 bahwa jumlah penderita kasus Demam Berdarah Dengue dengan kondisi lingkungan fisik rumah menurut curah hujan wilayah Puskesmas Purwokerto Selatan memiliki curah hujan rata-rata $3.940 \mathrm{~mm}$, dengan jumlah kasus di 7 kelurahan yaitu kelurahan Karangklesem 14 kasus, Teluk 17 kasus, Berkoh 6 kasus, Purwokerto Kidul 7 kasus, Purwokerto Kulon 6 kasus, Karangpucung 15 kasus, dan kelurahan Tanjung sebanyak 12 kasus. Wilayah kerja Puskesmas Purwokerto Selatan termasuk daerah yang beriklim tropis basah. Hujan berpengaruh terhadap kelembaban nisbi udara dan tempat perindukan nyamuk juga bertambah banyak. Curah hujan sangat penting untuk kelangsungan hidup nyamuk $A e$. aegypti, hujan akan mempengaruhi naiknya kelembaban nisbi udara dan menambah jumlah tempat perkembangan nyamuk Aedes sp di luar rumah.

c. Pencahayaan

Berdasarkan tabel 3.11 bahwa jumlah penderita kasus Demam Berdarah Dengue dengan kondisi lingkungan fisik rumah menurut pencahayaan pada kelurahan Karangklesem rata-rata pencahayaan di bagian dalam rumah 117 lux dan bagian luar rumah 455 lux, kelurahan Teluk pada bagian dalam 160 lux dan bagian luar 643 lux, Berkoh pada bagian dalam 126 lux dan pada bagian luar 374 lux, Purwokerto Kidul pada bagian dalam 96 lux dan bagian luar 449 lux, Purwokerto Kulon pada bagian dalam 112 lux dan pada bagian luar 326 lux, Karangpucung pada bagian dalam 212 lux dan pada bagian luar 411 lux, kelurahan Tanjung pada bagian dalam 87 lux dan bagian luar 445 lux.

Kondisi lingkungan fisik menurut pencahayaan diketahui bahwa ratarata pencahayaan di wilayah kerja Puskesmas Purwokerto Selatan untuk bagian dalam rumah adalah 130 lux, sedangkan untuk bagian luar rumah adalah 443 lux. Subyek tempat dengan rata-rata pencahayaan tertinggi adalah di kelurahan Karangpucung dengan rata-rata pencahayaan bagian dalam rumah adalah 212 lux dan pencahayaan bagian luar rumah terdapat di kelurahan Teluk dengan pencahayaan rata-rata 643 lux.

Nyamuk Aedes sp bersifat diurnal atau aktif pagi hingga siang hari pada pukul 08.00 - 12.00 dan 15.00 - 17.00 WIB, biasanya beristirahat pada benda - benda yang menggantung di dalam rumah dan pada tempat yang gelap. Tempat atau ruang yang gelap cenderung akan memiliki suhu dan 
kelembaban yang sesuai untuk pertumbuhan nyamuk tersebut.

d. Suhu udara

Berdasarkan tabel 3.12 bahwa jumlah penderita kasus Demam Berdarah Dengue dengan kondisi lingkungan fisik rumah menurut suhu udara pada kelurahan Karangklesem rata-rata suhu udara di bagian dalam rumah $32^{\circ} \mathrm{C}$ dan bagian luar rumah $32^{\circ} \mathrm{C}$, kelurahan Teluk pada bagian dalam $27^{\circ} \mathrm{C}$ dan bagian luar $32^{\circ} \mathrm{C}$, Berkoh pada bagian dalam $32^{\circ} \mathrm{C}$ dan pada bagian luar $32^{\circ} \mathrm{C}$, Purwokerto Kidul pada bagian dalam $30^{\circ} \mathrm{C}$ dan bagian luar $32^{\circ} \mathrm{C}$, Purwokerto Kulon pada bagian dalam $32^{\circ} \mathrm{C}$ dan pada bagian luar $32^{\circ} \mathrm{C}$, Karangpucung pada bagian dalam $34^{\circ} \mathrm{C}$ dan pada bagian luar $34^{\circ} \mathrm{C}$, kelurahan Tanjung pada bagian dalam $30^{\circ} \mathrm{C}$ dan bagian luar $30^{\circ} \mathrm{C}$.

Kondisi lingkungan fisik menurut suhu udara diketahui bahwa rata-rata suhu udara di wilayah kerja Puskesmas Purwokerto Selatan untuk bagian dalam rumah adalah $31^{\circ} \mathrm{C}$ sedangkan untuk bagian luar rumah adalah $32^{\circ} \mathrm{C}$. Subyek tempat dengan rata-rata pencahayaan tertinggi adalah di kelurahan Karangpucung dengan rata-rata suhu udara bagian dalam rumah dan bagian luar rumah adalah $34^{\circ} \mathrm{C}$. Nyamuk dapat bertahan hidup pada suhu rendah, tetapi metabolismenya menurun atau bahkan terhenti bila suhunya turun sampai dibawah suhu kritis. Pada suhu yang lebih tinggi dari $35^{\circ} \mathrm{C}$ juga mengalami perubahan dalam arti lebih lambatnya proses-proses fisiologis, rata-rata suhu optimum untuk pertumbuhan nyamuk adalah $25^{\circ} \mathrm{C}-27^{\circ} \mathrm{C}$. Pertumbuhan nyamuk akan terhenti sama sekali bila suhu kurang $10^{\circ} \mathrm{C}$ atau lebih dari $40^{\circ} \mathrm{C}$.

e. Kelembaban udara

Berdasarkan tabel 3.13 bahwa jumlah penderita kasus Demam Berdarah Dengue dengan kondisi lingkungan fisik rumah menurut kelembaban udara pada kelurahan Karangklesem rata-rata kelembaban udara di bagian dalam rumah $60 \%$ dan bagian luar rumah $62 \%$, kelurahan Teluk pada bagian dalam $62 \%$ dan bagian luar $70 \%$, Berkoh pada bagian dalam $70 \%$ dan pada bagian luar $70 \%$, Purwokerto Kidul pada bagian dalam $70 \%$ dan bagian luar $70 \%$, Purwokerto Kulon pada bagian dalam $70 \%$ dan pada bagian luar $72 \%$, Karangpucung pada bagian dalam $60 \%$ dan pada bagian luar $60 \%$, kelurahan Tanjung pada bagian dalam $70 \%$ dan bagian luar $70 \%$.

Kondisi lingkungan fisik menurut kelembaban udara diketahui bahwa rata-rata kelembaban udara di wilayah kerja Puskesmas Purwokerto Selatan untuk bagian dalam rumah adalah $66 \%$ sedangkan untuk bagian luar rumah adalah $62 \%$. Subyek tempat dengan rata-rata kelembaban tertinggi adalah di kelurahan Purwokerto Kidul, Purwokerto Kulon, dan Tanjung dengan rata-rata kelembaban udara bagian dalam rumah $70 \%$ dan bagian luar rumah di kelurahan Purwokerto Kulon adalah $72 \%$.

Kebutuhan kelembaban tinggi mempengaruhi nyamuk untuk mencari tempat yang lembab dan basah sebagai tempat hinggap atau istirahat seperti kamar tidur dan kolong-kolong merupakan tempat yang sesuai sebagai tempat peristirahatan nyamuk di dalam rumah, dengan tingkat kelembaban optimum adalah $60 \%$ $80 \%$. Dan wilayah kerja Puskesmas Purwokerto Selatan memiliki kondisi kelembaban yang sesuai bagi nyamuk.

f. Jenis tempat penampungan air/ tempat perindukan (TPA)

Berdasarkan tabel 3.14 bahwa jumlah penderita kasus Demam Berdarah Dengue dengan kondisi lingkungan fisik rumah menurut jenis tempat penampungan air/ tempat perindukan (TPA) di kelurahan Karang klesem terdapat container berupa bakmandi sebanyak 12 , tempayan 6 , pot/ vas 10, dispenser 14, kulkas 9, ember 2, dan kolam 1. Kelurahan Teluk terdapat container berupa bak mandi 12 , tempayan 10 , pot/ vas 12 , dispenser 10, kulkas 16, ember 3, akarium 1, dan barang-barang bekas 1. Kelurahan Berkoh ditemukan container berupa bak mandi 5, tempayan 5 , pot/ vas 4 , dispenser 2 , kulkas 5, dan ember 2. Kelurahan Purwokerto Kidul container yang ditemukan adalah bak mandi 5, tempayan 5 , pot/ vas 5 , dispenser 1 , kulkas 6 , dan ember 2. Kelurahan Purwokerto Kulon container yang ditemukan adalah bak mandi 8, tempayan 3 , pot/ vas 10 , dispenser 10 , kulkas 11, dan ember 1 . Kelurahan Karangpucung container yang ditemukan adalah bak mandi 5, tempayan 5 , pot/ vas 5 , dispenser 1 , kulkas 6 , ember 7 dan tempat minum 
burung 2. Kelurahan Tanjung container yang ditemukan adalah bak mandi 7 , tempayan 9, pot/ vas 7, dispenser 7 , kulkas 10, ember 4, kolam 1 dan barang-barang bekas 1 .

Kondisi lingkungan fisik menurut jenis tempat penampungan air/ tempat perindukan (TPA) diketahui bahwa jumlah container yang telah diperiksa di wilayah kerja Puskesmas Purwokerto Selatan adalah 285 container. Dari 285 container yang ditemukan terdapat 7 container yang ditemukan positif keberadaan jentik. Container tersebut adalah bak mandi, dispenser, dan pot/ vas bunga. Tempat tersebut dapat menjadi container karena keberadaannya yang tergenang air yang tidak kontak langsung dengan tanah, berada ditempat yang kurang terang dan lembab serta karena masyarakat jarang membersihkan tempat-tempat yang tidak terduga menjadi tempat yang potensial bagi nyamuk Aedes untuk bertelur di rumah, sehingga ditemukan adanya jentik dan sangat berpotensi menjadi tempat perkembangbiakkan bagi nyamuk.

g. Kepadatan jentik

Dari hasil data yang telah dikumpulkan melalui kegiatan survei yang dilakukan di wilayah kerja Puskesmas Purwokerto Selatan yang mencakup 7 kelurahan yaitu kelurahan Krangklesem, Teluk, Berkoh, Purwokerto Kidul, Purwokerto Kulon, Karangpucung, dan kelurahan Tanjung dengan subyek penelitian sebanyak 77 rumah didapatkan hasil untuk Container index/ (C.I) didapatkan hasil $2,45 \%$. Menurut WHO batas untuk C.I adalah $\leq 5 \%$, sehingga sudah memenuhi karena kontainer yang ditemukan jentik kurang dari/ sama dengan 5\%. Untuk House index/ (H.I) didapatkan hasil 9,09\%. Menurut WHO, hasil tersebut sudah memenuhi karena berada pada batas $\leq 10 \%$. Untuk Breteau index/ (B.I) ditemukan hasil $9,09 \%$, dan menurut $\mathrm{WHO}$ hasil tersebut sudah memenuhi syarat karena $\leq 50 \%$. Dan hasil perhitungan ABJ ditemukan hasil 90,9\%, dan hasil tersebut menurut WHO kurang dari batas karena persyaratan angka bebas jentik adalah $\geq 95 \%$.

Dari hasil perhitungan kepadatan jentik untuk C.I, H.I dan B.I sudah memenuhi kriteria menurut WHO, sedangkan untuk ABJ belum mencapai angka $\geq 95 \%$ sehingga belum mencapai batas maksimal karena masih ditemukan keberadaan jentik di beberapa rumah sehingga perlu dilakukan adanya upaya untuk pengendalian larva/ jentik. Dan mayarakat disarankan secara rutin agar melakukan pemberantasan sarang nyamuk sehingga kasus DBD dapat dihilangkan atau diturunkan.

\section{SIMPULAN DAN SARAN}

\section{A. Simpulan}

Dari hasil data yang telah dikumpulkan melalui kegiatan survei yang dilakukan di wilayah kerja Puskesmas Purwokerto Selatan yang mencakup 7 kelurahan yaitu kelurahan Krangklesem, Teluk, Berkoh, Purwokerto Kidul, Purwokerto Kulon, Karangpucung, dan kelurahan Tanjung dengan subyek penelitian sebanyak 77 rumah didapatkan hasil berikut:

1. Ketinggian tempat wilayah Puskesmas Purwokerto Selatan adalah $\pm 74 \mathrm{~m}$ dari permukaan laut.

2. Puskesmas Purwokerto Selatan memiliki rata-rata curah hujan $3.940 \mathrm{~mm}$.

3. Rata-rata pencahayaan di wilayah kerja Puskesmas Purwokerto Selatan pada bagian dalam rumah adalah 130 lux, sedangkan pada bagian luar rumah adalah 443 lux.

4. Suhu udara rata-rata di wilayah kerja Puskesmas Purwokerto Selatan pada bagian dalam rumah adalah $31^{\circ} \mathrm{C}$ sedangkan pada bagian luar rumah adalah $32^{\circ} \mathrm{C}$.

5. Kelembaban udara rata-rata di wilayah kerja Puskesmas Purwokerto Selatan pada bagian dalam rumah adalah $66 \%$ sedangkan pada bagian luar rumah radalah $62 \%$.

6. Jumlah container yang telah diperiksa di wilayah kerja Puskesmas Purwokerto Selatan adalah 285 container dengan jenis container berupa bak mandi, tempayan, pot/ vas, dispenser, kulkas, ember, akuarium, kolam, barang bekas, dan tempat minum burung.

7. Container index/ (C.I) adalah 2,45\%. Menurut WHO batas C.I adalah $\leq 5 \%$, sehingga sudah memenuhi karena kontainer yang ditemukan jentik kurang dari/ sama dengan $5 \%$.

8. House index/ (H.I) adalah 9,09\%. Menurut $\mathrm{WHO}$, hasil tersebut sudah memenuhi karena berada pada batas $\leq$ $10 \%$.

9. Breteau index/ (B.I) adalah 9,09 \%, dan menurut $\mathrm{WHO}$ hasil tersebut sudah memenuhi karena $\leq 50 \%$. 
10. Angka Bebas Jentik/ (ABJ) adalah 90,9 $\%$, dan hasil tersebut menurut WHO kurang memenuhi karena batas angka bebas jentik adalah $\geq 95 \%$.

\section{B. Saran}

1. Kepada masyarakat

a. Diharapkan selalu membersihkan tempat penampungan air minimal satu minggu sekali, khususnya kepada masyarakat Kelurahan Karangpucung.

b. Kepada responden yang memiliki rumah kurang terang atau gelap sebaiknya diberi cahaya alami dengan menambah ventilasi jendela atau seng/ genteng tembus cahaya pada atap rumah.

2. Kepada Instansi terkait

a. Dinas Kesehatan diharapkan selalu melakukan pemberantasan sarang nyamuk dengan melakukan 3M plus yang sudah menjadi program dari pemerintah.

b. Puskesmas Purwokerto Selatan sebaiknya lebih memantau kaderkader PSN di setiap kelurahan secara rutin melakukan pemberantasan sarang nyamuk setiap seminggu sekali.

\section{DAFTAR PUSTAKA}

Badan Pusat Statistik Kabupaten Banyumas, 2013 a, Data Mencerdaskan Bangsa, Purwokerto : Badan Pusat Statistik Kabupaten Banyumas

2013 b, Kecamatan Purwokerto Selatan Dalam Angka 2013, Purwokerto : Badan Pusat Statistik Kabupaten Banyumas \& Badan Perencanaan Pembangunan Daerah Kabupaten Banyumas

Cecep Dani Sucipto, 2011, Vektor Penyakit Tropis, Yogyakarta : Gosyen Publishing

Departemen Kesehatan R.I. Direktorat Jenderal Pengendalian Penyakit Dan Penyehatan Lingkungan (DIT.JEN. PP \& PL), 2007 a, Survai Entomologi Demam Berdarah Dengue, Jakarta : DIT.JEN. PP \& PL
), 2007 b, Ekologi dan Aspek

Perilaku Vektor, Jakarta : DIT.JEN. PP \& $\mathrm{PL}$

Dinar Prisma Antari, 2013, Studi Hubungan Angka Bebas Jentik (ABJ) dengan Insiden Demam Berdarah Dengue (DBD) Di Daerah Endemis Di Wilayah Kabupaten Banyumas 2008-2012, Purwokerto : Kemenkes RI Politeknik Kesehatan Semarang Jurusan Kesehatan Lingkungan Purwokerto

Fendi Bagus Setyawan, 2013, Studi Komparasi Ovitrap Index pada Daerah Endemis dan Non Endemis DBD DI Kecamatan Banjarnegara Kabupaten Banjarnegara Tahun 2013, Purwokerto : Kemenkes RI Politeknik Kesehatan Semarang Jurusan Kesehatan Lingkungan Purwokerto

Handrawan Nasedul, 2007, Cara Mengalahkan Demam Berdarah, Jakarta : Buku Kompas, Mei 2007

Irna Uswatul Hasanah, 2012, Faktor-Faktor Lingkungan Fisik Rumah yang Berhubungan dengan Kejadian Penyakit DBD Di Wilayah Puskesmas Banjarnegara I Kabupaten Banjarnegara Tahun 2012, Purwokerto : Kemenkes RI Politeknik Kesehatan Semarang Jurusan Kesehatan Lingkungan Purwokerto

Ririh Yudhastuti, 2011, Pengendalian Vektor dan Rodent, Surabaya : Pustaka Melati

Tri Cahyono, 2012, Pedoman Penulisan Proposal Penelitian Dan Karya Tulis IImiah/ Skripsi Edisi Revisi Ketiga, Purwokerto : Kemenkes RI Politeknik Kesehatan Semarang Jurusan Kesehatan Lingkungan Purwokerto

World Health Organization / Organisasi
Kesehatan Dunia (WHO), Demam
Berdarah Dengue :
Pengobatan, Diagnosis,
Pengendalian Edisi 2, Jakarta : Penerbit
Buku Kedokteran EGC

